\title{
EVALUATION OF ANTIPYRETIC AND ANTIULCER ACTIVITY OF ETHANOLIC EXTRACT OF LEAVES OF TREMA ORIENTALIS L. IN ALBINO WISTAR RATS
}

\author{
VANITA G KANASE*, JYOTI SINGH
}

Department of Pharmacology, Oriental College of Pharmacy, Navi Mumbai, Maharashtra, India. Email: vanita.kanase@gmail.com

Received: 21 September 2019, Revised and Accepted: 26 October 2019

\section{ABSTRACT}

Objectives: The purpose of the present study was aimed at evaluating the antipyretic and antiulcer activity on leaves of Trema orientalis L. (family Cannabaceae) on albino Wistar rats. The antipyretic and antiulcer activity of the ethanolic extract of the T. orientalis L. leaves in three different concentrations $(100,200$, and $300 \mathrm{mg} / \mathrm{kg})$ was compared with standard paracetamol and pantoprazole, which was evaluated by employing Brewer's yeast-induced pyrexia and ethanol-induced ulcer model. The biochemical parameters such as the volume of gastric juice secretion, $\mathrm{pH}$, total acidity, ulcer index, percentage protection, and lipid peroxidation were also studied.

Methods: T. orientalis leaves were extracted with ethanol by the Soxhlet extraction method. The dried extract was used for further phytochemical and pharmacological analysis. The antipyretic effect was studied using Brewer's yeast-induced pyrexia. The ethanol-induced ulcer model was used to study the antiulcer effect.

Results: The percentage yield of ethanolic extract of $T$. orientalis leaves was found to be $6.71 \%$ w/w, respectively. The extract showed significant antipyretic and antiulcer effect when compared with standard paracetamol and pantoprazole.

Conclusion: The ethanolic extract of T. orientalis has significant antipyretic and antiulcer action.

Keywords: Trema orientalis L., Antiulcer activity, Ethanol-induced ulcer, Ulcer index.

(C) 2019 The Authors. Published by Innovare Academic Sciences Pvt Ltd. This is an open access article under the CC BY license (http://creativecommons. org/licenses/by/4. 0/) DOI: http://dx.doi.org/10.22159/ajpcr.2019.v12i12.35808

\section{INTRODUCTION}

\section{Peptic ulcer}

The peptic ulcer is characterized by an area of the gastrointestinal tract (GIT) which has been damaged by gastric acid or pepsin. A peptic ulcer can refer to gastric ulcer, duodenal ulcer, or esophageal ulcer. The peptic ulcer is characterized by an area of the GIT which has been damaged by gastric acid or pepsin. A peptic ulcer can refer to gastric ulcer, duodenal ulcer, or esophageal ulcer [1]. Peptic ulcer is one of the major gastrointestinal disorders and it affecting about $10 \%$ of the world population. About 15000 deaths occur every year due to the consequences of peptic ulcer [2]

Trema orientalis is a species of flowering tree in the hemp family, Cannabaceae. It is known by many common names, including charcoaltree, Indian charcoal-tree, pigeon wood, and oriental trema. T. orientalis is widely distributed all over the world in countries. Species in this family are significant in food. T. orientalis is used in the treatment of antidiabetic [3,4], antiplasmodial and antimicrobial [5-7], diuresis [8], anticonvulsant [9], anti-inflammatory and anti-arthritic [8,10], antibacterial [11,12], antihelmintic [12,13], antisickling [14], and antioxidant activity [15]. The leaves of $\mathrm{T}$. orientalis contain tannins, saponins, flavonoids, and triterpenoid (simiarenol, simiarenone, and tramadol) [16]. T. orientalis plants are used in folk medicine for the treatment of trauma, blood stasis, hematuria, and bleeding of intestines and stomach [17]. Flavonoids are among the cytoprotective materials for which antiulcerogenic efficacy has been extensively confirmed [18-20], they protect the gastric mucosa against a variety of ulcerogenic agents through several mechanisms of action, mainly free-radical scavenging and antioxidant properties, increased mucus production, antisecretory action, and inhibition of the Helicobacter pylori growth (Fig. 1) [19].

\section{METHODS}

Animals

Male albino Wistar rats (180-220 g) were used for the study. The animals were obtained from Bharat Serums and Vaccines Limited,
Thane West, Maharashtra 400604. The rats were housed in the standard polypropylene rat cages, which were covered by stainless steel coverlids. Wheat husk was used as bedding material. The animals were kept at the animal house of Oriental College of Pharmacy, Sanpada, Navi Mumbai. Standard environmental conditions such as photoperiod (12:12 h dark:light cycle) and temperature $\left(22 \pm 2^{\circ} \mathrm{C}\right)$ were maintained. Rats were provided with commercial rat feed and water given ad libitum. The use of these animals and the study protocols was approved by CPCSEA recognized Institutional Animal Ethics Committee (IAEC) of Oriental College of Pharmacy, Sanpada, Navi Mumbai - 400705 under protocol no. OCP/IAEC/2017-18/03.

\section{Drugs and chemicals}

Paracetamol and pantoprazole were obtained from Cipla Ltd., and ethanol was obtained from Thomas Baker Chemicals, Brewer's yeast powder (now foods). All other chemicals used in this study were obtained commercially and were of analytical grade.

\section{Plant material}

The fresh leaves of T. orientalis L. were collected from Ghodbunder Road, Thane West, Mumbai, in June 2017 and were submitted to Dr. Bindoo Gopal Krishnan Assistant Professor Department of Botany at Mithibai College of Arts, Chauhan Institute of Science and Amruthben Jivanlal College of Commerce and Economics. The leaves were washed with tap water and shade dried at normal room temperature with the aid of circulating airflow using the fan. Then, leaves were ground to make a coarse powder. The powder was stored in a suitable container. This powder was subjected to Soxhlet extraction.

The extracts obtained from the Soxhlet were evaporated to obtain the dry powder of extract. This crude dry extract was stored in suitable container and kept in refrigerator $4^{\circ} \mathrm{C}$ until use. The percentage yield of ethanol extract was $6.71 \% \mathrm{w} / \mathrm{w}$. The ethanol extract of T. orientalis $\mathrm{L}$. was used for the entire study. 


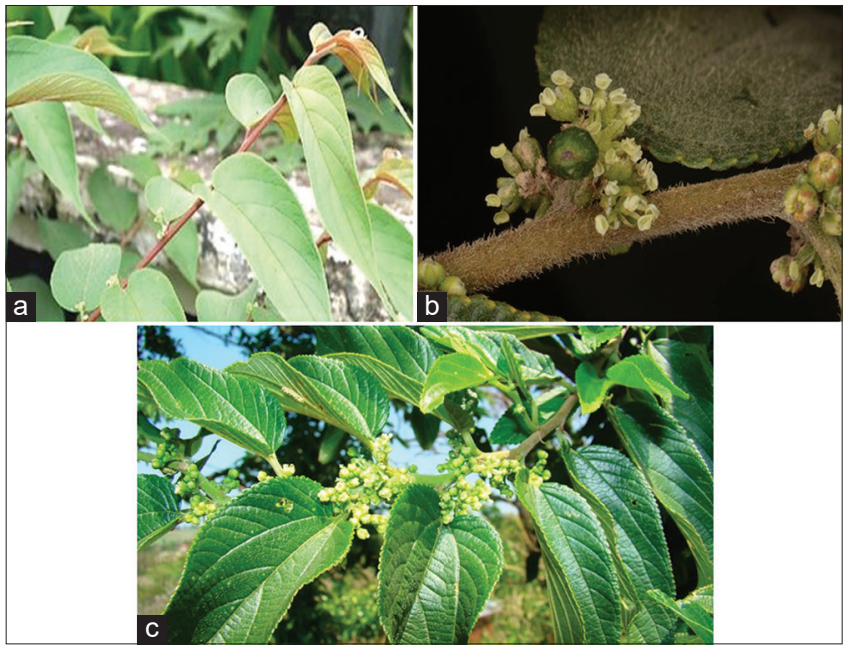

Fig. 1: (a-c) Leaves of Trema orientalis $\mathrm{L}$

\section{Qualitative phytochemical screening}

Preliminary chemical tests were carried out on ethanolic extract of T. orientalis L. for determination of the presence of different phytoconstituents. All tests were performed by the procedures given in "practical pharmacognosy" by Dr. Khandelwal [21].

\section{Preparation of Ethanolic extract of T. orientalis (EETO) stock} suspension

To prepare the stock suspension of $10 \mathrm{mg} / \mathrm{ml}$ of EETO, the EETO powder was taken in mortar and pestle and crushed to get it into a fine consistency. This powder was then passed through the 80\# sieve. About $0.2 \%$ carboxymethyl cellulose in $1000 \mathrm{ml}$ saline water was mixed in parts with $10 \mathrm{~g}$ of the fine powder to get a $10 \mathrm{mg} / \mathrm{ml}$ suspension of EETO.

\section{Selection of doses}

Protocol no. OCP/IAEC/2018-19/02 conducted acute oral toxicity study prescribed by the OECD guideline 423 and the results suggested that there were no toxic signs observed in clinical parameters during acute toxicity study up to $2000 \mathrm{mg} / \mathrm{kg}$. Hence, it indicates that the $\mathrm{LD}_{50}$ of the ethanolic extract of T. orientalis leaves formulation is $>2000 \mathrm{mg} \mathrm{kg}$. The doses for the groups were selected as $100 \mathrm{mg} / \mathrm{kg}, 200 \mathrm{mg} / \mathrm{kg}$, and $300 \mathrm{mg} / \mathrm{kg}$

\section{Antipyretic study}

Brewer's yeast induced pyrexia model in one of the common models for induction of pyrexia. This model was used by various researchers such as Hossain et al. and Akapa et al. [16,22,23]. Yeast is able to produce the pyrogens in the body, causing generation of immune response, thus ultimately leading to the synthesis and release of prostaglandins, which is the final fever mediator in the brain, particularly in the preoptic area of the anterior hypothalamus.

The animals were divided into five groups (six animals in each group) for antipyretic studies:

Group I (negative): They received 20\% yeast suspension

Group II (standard): They received paracetamol $150 \mathrm{mg} / \mathrm{kg}$

Group III (test 1): They received EETO $100 \mathrm{mg} / \mathrm{kg}$

Group IV (test 2): They received EETO $200 \mathrm{mg} / \mathrm{kg}$

Group V (test 3): They received EETO $300 \mathrm{mg} / \mathrm{kg}$.

\section{Procedure}

The normal body temperature of each rat was measured rectally and recorded. Pyrexia was induced by injecting $10 \mathrm{ml} / \mathrm{kg}$ body weight of $20 \%$ brewer's yeast suspension in saline solution into the subcutaneous route. Hick's digital thermometer coated with the lubricant was inserted 3-4 cm deep into the rectum and basal temperature was recorded. After $18 \mathrm{~h}$ of yeast injection, each group receives the respective oral dosage of control/standard/test drug [24-28].
The temperature was recorded at 30,60, 90, 120, 150, and 300 min after yeast injection. Rectal temperature before and after treatment was compared and the percentage change in rectal temperature was calculated by the following formula:

$$
\begin{aligned}
\text { Percent inhibition of } \\
\text { rectal temperature }
\end{aligned}=\frac{\begin{array}{l}
\text { Temperature at time } \\
\text { Inial temperature }
\end{array}}{\text { Initial temperature }} \times 100
$$

Behavioral changes before and after injection of yeast suspension was also monitored.

\section{Ethanol-induced gastric ulcer model}

Ethanol-induced gastric ulcer model is used on rats and is one of the widely used models due to its principle involving the cytoprotective action. Ethanol causes damage to the superficial epithelial layers, as well as is known to inhibit the prostaglandin release. It also increases the concentration of blood neutrophils, causing microcirculatory abnormality and generation of reactive oxygen species, leading to activation of $\mathrm{H}^{+} / \mathrm{K}^{+}$ATPase, i.e., proton-pump, which leads to acid hypersecretion, causing damage to GI mucosa [29]

Pantoprazole is widely used, one the most commonly used drugs to treat gastric ulcers. It belongs to the class of proton-pump inhibitors, which is the end step in secretion of gastric acid. Proton-pump inhibitors are prodrugs, which underwent sulfenamide cation form and irreversibly bind to the sulfhydryl group of $\mathrm{H}^{+} / \mathrm{K}^{+}$ATPase, causing complete inhibition of the acid secretion [30]. It also provides this activity on nocturnal acid secretion [31]. Any chemical agent that prevents the ethanol-induced ulcers might have the cytoprotective activity and may exert its action by stimulating the release of endogenous prostaglandins, as well as mucin. Similarly, this model can be used to screen possible antisecretory activity effectively.

\section{Procedure}

The animals were divided into six groups (six animals in each group) for antiulcer studies [32-35].

Group I (normal): They received distilled water Group II (negative): They received ethanol $5 \mathrm{ml}$ Group III (standard): They received pantoprazole $20 \mathrm{mg} / \mathrm{kg}$ Group IV (test 1): They received EETO $100 \mathrm{mg} / \mathrm{kg}$ Group V (test 2): They received EETO $200 \mathrm{mg} / \mathrm{kg}$ Group VI (test 3): They received EETO $300 \mathrm{mg} / \mathrm{kg}$.

Ethanol-induced gastric ulcer method was done by the mechanism given by Oates and Hakkinen [32]. The ulcer was induced by ethanol 95\% (absolute ethanol). Male albino Wistar rats were divided into six groups. Six rats in each group, all groups were under a fasting state for $24 \mathrm{~h}$; however, they were allowed to drink water. The purpose of fasting was to inhibit the cross-reaction of gastric content with administered treatments. All rats were orally given particular pre-treatment based on their groups and their weight. After $24 \mathrm{~h}$, test groups 1, 2, and 3 were administered with ethanolic extract of T. orientalis L. leaves $(100$, 200 , and $300 \mathrm{mg} / \mathrm{kg}$, p.o.), the standard group received pantoprazole (20 mg/kg, p.o.). The control group received vehicle (distilled water). Two hours after drug treatment, the animals were sacrificed in the $\mathrm{CO}_{2}$ chamber and dissected to extract their stomach. Stomachs are cut open along the greater curvature, and content of the stomachs was collected in test tubes for evaluation of gastric volume, total acidity, lipid peroxidation (LPO), and $\mathrm{pH}$. Then, stomachs were gently rinsed with $0.9 \%$ saline solution and mounted on the wax plate.

\section{Determination volume of gastric content, total acidity, and $\mathrm{pH}$} Gastric contents of each rat were collected in the test tubes and their volume was determined. To determine the $\mathrm{pH}, 1 \mathrm{ml}$ of distilled water is added to the $1 \mathrm{ml}$ aliquot of gastric juice. With help of $\mathrm{pH}$ meter, the $\mathrm{pH}$ of the resultant solution was measured. To determine the total acidity, $1 \mathrm{ml}$ gastric juice was diluted by addition of $1 \mathrm{ml}$ distilled water. The resultant solution was transferred to the conical flask and 
titrated against the $0.01 \mathrm{~N} \mathrm{NaOH}$ with few drops of phenolphthalein solution as an indicator. The total acidity was determined by the following formula [36-39]:

$$
\text { Total acidity }=\left(\frac{\text { Vol. of } \mathrm{NaOH} \times 0.01}{0.1}\right) \times 100
$$

\section{Evaluation of antiulcer activity}

For determination of protection from the ulcer, ulcer index (UI) given by Ganguly and Bhatnagar was used, which is as follows [40,41]:

Normal colored stomach - (0), red coloration - (0.5), spot ulcer - (1), hemorrhagic streak - (1.5), deep ulcers - (2), perforation - (3)

UI was measured using following formula:

$$
\mathrm{UI}=(\mathrm{UN}+\mathrm{US}+\mathrm{UP}) \times 10^{-1}
$$

Where,

UI: Ulcer index

UN: Average number of ulcers per animal

US: Average number of severity score

UP: Percentage of animals with ulcers.

Similarly, from the data obtained after using the above equation, percent protection was determined using the following formula:

Table 1: Result of physicochemical analysis of powdered leaves of Trema orientalis $\mathrm{L}$.

\begin{tabular}{lll}
\hline S. No. & Test & Result (\%) \\
\hline 1. & Water-soluble extractive value & 5 \\
2. & Ethanol-soluble extractive value & 6.71 \\
3. & Chloroform-soluble extractive value & 0.12 \\
4. & Benzene-soluble extractive value & 0.52 \\
5. & Petroleum-ether soluble extractive value & 2.72 \\
\hline
\end{tabular}

Table 2: Result of quantitative phytochemical analysis of powdered leaves of Trema orientalis $\mathrm{L}$.

\begin{tabular}{lll}
\hline S. No. & Phytoconstituents & $\begin{array}{l}\text { Ethanolic extract of the leaves } \\
\text { Trema orientalis } \mathbf{L} .\end{array}$ \\
\hline 1. & Alkaloids & Present \\
2. & Flavonoids & Present \\
3. & Cardiac glycosides & Present \\
4. & Saponins & Absent \\
5. & Steroids & Absent \\
6. & Terpenoids & Present \\
7. & Tannins and phenolic & Present \\
& compounds & \\
8. & Carbohydrates & Absent \\
9. & Protein & Present \\
\hline
\end{tabular}

$$
\text { Percent protection }=\left(\frac{\text { UIa }- \text { UIt }}{\text { UIa }}\right) \times 100
$$

Where,

UIa: UI of ulcer control group

UIt: UI of test groups.

Furthermore, another method to determine the area of stomach affected by ulcer was suggested by Rathod et al. 2014, which requires the use of ImageJ software [42]. Using this software, the total area of the antrum and the total ulcerated area was determined, and from this, percent protection was calculated with the following formula:

$$
\text { Percent protection }=\left(\frac{\mathrm{UAa}-\mathrm{UAt}}{\mathrm{UAa}}\right) \times 100
$$

Where,

UAa: Ulcerated area of ulcer control group

UAt: Ulcerated area of test groups.

Biochemical estimation of LPO from post mitochondrial
supernatant (PMS) Procedure

The stomach was homogenized in chilled phosphate buffer (pH 7.4) using a homogenizer. The homogenates were centrifuged at $800 \mathrm{rpm}$ for $5 \mathrm{~min}$ at $4^{\circ} \mathrm{C}$ to separate the molecular debris. The supernatant so obtained was centrifuged at $10,000 \mathrm{rpm}$ for $20 \mathrm{~min}$ at $4^{\circ} \mathrm{C}$ to get the PMS [43,44].

About $0.5 \mathrm{ml}$ of PMS was taken and to it was added $0.5 \mathrm{ml}$ of tris hydrogen chloride buffer and incubated at $37^{\circ} \mathrm{C}$ for $2 \mathrm{~h}$, and then $1 \mathrm{ml}$ of ice-cold trichloroacetic acid was added, centrifuged at $1000 \mathrm{rpm}$ for $10 \mathrm{~min}$. From the above, $1 \mathrm{ml}$ of supernatant was taken and added $1 \mathrm{ml}$ of thiobarbituric acid and the tubes were kept in boiling water bath for $10 \mathrm{~min}$. The tubes were removed and brought up to room temperature and $1 \mathrm{ml}$ of distilled water was added. Absorbance was measured at $532 \mathrm{~nm}$ using a UV-visible spectrophotometer.

Blank

It was prepared without tissue homogenate.

$$
\text { Calculation }=\frac{3 \times \text { Absorbance of sample }}{50.156 \times(\mathrm{mg} \text { of tissue taken }}=\mu \mathrm{m} / \mathrm{mg} \text { tissue }
$$

\section{Statistical analysis}

The data were analyzed with InStat Software by GraphPad (version 3.10). The results are expressed as the mean \pm standard error of mean for each group. Statistical differences were evaluated using a one-way analysis of variance followed by Dunnett's t-test.

\section{RESULTS}

\begin{tabular}{|c|c|c|c|c|c|c|c|}
\hline Group & $0 \mathrm{~min}$ & $30 \mathrm{~min}$ & $60 \mathrm{~min}$ & $90 \mathrm{~min}$ & $120 \mathrm{~min}$ & $150 \mathrm{~min}$ & $300 \mathrm{~min}$ \\
\hline Yeast control & $104.58 \pm 0.315$ & $104.83 \pm 0.041$ & $105.03 \pm 0.374^{\# \#}$ & $105.19 \pm 0.178^{\# \#}$ & $105.25 \pm 0.108^{\# \#}$ & $105.42 \pm 0.180^{\# \#}$ & $105.67 \pm 0.170^{\# \#}$ \\
\hline Standard & $103.60 \pm 0.231$ & $104.42 \pm 0.279$ & $103.13 \pm 0.382^{* *}$ & $102.41 \pm 0.350^{* *}$ & $102.06 \pm 0.365^{* *}$ & $101.68 \pm 0.375^{* *}$ & $101.07 \pm 0.477^{* *}$ \\
\hline Test 1 (EETO & $104.18 \pm 0.557$ & $104.25 \pm 0.649$ & $104.25 \pm 0.482$ & $103.80 \pm 0.504^{* \#}$ & $103.39 \pm 0.533^{* * \#}$ & $103.08 \pm 0.570^{* * \#}$ & $102.50 \pm 0.618^{* *}$ \\
\hline 100 mg/kg) & & & & & & & \\
\hline $\begin{array}{l}\text { Test } 2 \text { (EETO } \\
200 \mathrm{mg} / \mathrm{kg})\end{array}$ & $105.80 \pm 0.354^{\# \#}$ & $105.23 \pm 0.160$ & $104.85 \pm 0.171^{\#}$ & $103.92 \pm 0.256^{\#}$ & $103.15 \pm 0.162^{* *}$ & $102.87 \pm 0.282^{* *}$ & $102.37 \pm 0.325^{* *}$ \\
\hline $\begin{array}{l}\text { Test } 3 \text { (EETO } \\
300 \mathrm{mg} / \mathrm{kg})\end{array}$ & $104.12 \pm 0.293$ & $103.48 \pm 0.427$ & $103.30 \pm 0.414^{*}$ & $103.04 \pm 0.363^{* *}$ & $102.71 \pm 0.296^{* *}$ & $102.01 \pm 0.279^{* *}$ & $101.38 \pm 0.246^{* *}$ \\
\hline
\end{tabular}

Physicochemical analysis of powdered leaves

Physicochemical analysis of powdered leaves is mentioned in Table 1.

Table 3: Effect of ethanolic extract of Trema orientalis L. leaves on percent change in rectal temperature in yeast-induced pyrexia in albino Wistar rats

Values are the mean \pm standard error of mean of $n=6$ rats/treatment, significance ${ }^{*} *$ indicates $p \leq 0.01,{ }^{*}$ indicates $p \leq 0.05$ when compared with negative control, when compared with standard, significance ${ }^{\# \#} \mathrm{p} \leq 0.01, \# \mathrm{p} \leq 0.05$ 
Table 4: Effect of ethanolic extract of Trema orientalis L. leaves on ulcer index and percent ulcer in albino Wistar rats

\begin{tabular}{lllll}
\hline Groups & $\begin{array}{l}\text { Ulcer index } \\
\text { (Ganguly and Bhatnagar) }\end{array}$ & Percent protection & $\begin{array}{l}\text { Percent ulcer } \\
\text { (ImageJ Software) }\end{array}$ & Percent protection \\
\hline Normal control & - & - & - & - \\
Ulcer control & $14.50 \pm 0.67^{\# \#}$ & - & $18.48 \pm 3.26^{\# \#}$ & - \\
Standard (pantoprazole) & $4.83 \pm 0.60^{* *}$ & $66.33^{* *}$ & $0.69 \pm 0.32^{* *}$ & $99.31^{* *}$ \\
Test 1 (100 mg/kg EETO) & $9.53 \pm 0.32^{* * \# \#}$ & $34.00^{* * \# \#}$ & $3.20 \pm 1.16^{* *}$ & $96.80^{* *}$ \\
Test 2 (200 mg/kg EETO) & $7.13 \pm 0.19^{* * \#}$ & $50.33^{* * \# \#}$ & $1.36 \pm 0.42^{* *}$ & $98.64^{* *}$ \\
Test 3 (300 mg/kg EETO) & $4.93 \pm 0.549^{* *}$ & $65.33^{* *}$ & $0.98 \pm 0.814^{* *}$ & $99.02^{* *}$ \\
\hline
\end{tabular}

Values are the mean \pm standard error of mean of $\mathrm{n}=6$ rats/treatment. Significance $* * \mathrm{p} \leq 0.01$, ${ }^{\text {indicates }} \mathrm{p} \leq 0.05$ when compared with negative control, when compared with standard. Significance ${ }^{\#} \mathrm{p} \leq 0.01,{ }^{\mathrm{p}} \mathrm{p} \leq 0.05$

Table 5: Effect of ethanolic extract of Trema orientalis L. leaves on gastric volume, total acidity, and pH of gastric juice in albino Wistar rats

\begin{tabular}{lll}
\hline Group & Gastric volume (ml/100 g) & Total acidity (mEq/L) \\
\hline Normal control & $2.12 \pm 0.070^{* *}$ & $2.36 \pm 0.03^{\# \#}$ \\
Alcohol control & $3.97 \pm 0.249^{\# \#}$ & $1.01 \pm 0.01^{\# \#}$ \\
Standard (pantoprazole) & $2.172 \pm 0.200^{* *}$ & $7.94 \pm 0.22^{* *}$ \\
Test 1 (100 mg/kg EETO) & $1.99 \pm 0.411^{* *}$ & $13.23 \pm 0.59^{* * \# \#}$ \\
Test 2 (150 mg/kg EETO) & $2.26 \pm 0.095^{* *}$ & $9.94 \pm 0.14^{* * \# \#}$ \\
Test $3(250 \mathrm{mg} / \mathrm{kg}$ EETO) & $1.86 \pm 0.212^{* *}$ & $7.53 \pm 0.90^{* *}$ \\
\hline
\end{tabular}

Values are the mean \pm standard error of mean of $n=6$ rats/treatment. Significance ${ }^{* *} \mathrm{p} \leq 0.01,{ }^{*}$ indicates $\mathrm{p} \leq 0.05$ when compared with negative control, when compared with standard. Significance ${ }^{\# \#} \mathrm{p} \leq 0.01, " \# \mathrm{p} \leq 0.05$

Table 6: Effect of ethanolic extract of Trema orientalis L. leaves on lipid peroxidation value in albino Wistar rats

\begin{tabular}{lll}
\hline S. No. & Treatment & Lipid peroxidation \\
\hline 1. & Normal control & $1.09 \pm 0.58^{* *}$ \\
2. & Alcohol control & $3.75 \pm 0.35^{\# \#}$ \\
3. & Standard (pantoprazole) & $1.40 \pm 0.180^{* *}$ \\
4. & Test $1(100 \mathrm{mg} / \mathrm{kg}$ EETO) & $3.31 \pm 0.28^{\# \#}$ \\
5. & Test $2(200 \mathrm{mg} / \mathrm{kg}$ EETO) & $1.74 \pm 0.40^{* *}$ \\
6. & Test $3(300 \mathrm{mg} / \mathrm{kg}$ EETO) & $1.60 \pm 0.36^{* *}$ \\
\hline
\end{tabular}

Values are the mean \pm standard error of mean of $n=6$ rats/treatment. Significance ${ }^{* *} \mathrm{p} \leq 0.01,{ }^{*}$ indicates $\mathrm{p} \leq 0.05$ when compared with a negative control, when compared with standard. Significance ${ }^{\# \#} \mathrm{p} \leq 0.01, " \mathrm{p} \leq 0.05$

Qualitative phytochemical screening

Qualitative phytochemical screening is mentioned in Table 2.

\section{Antipyretic study}

All three test groups of the ethanolic extract of leaves of $T$. orientalis $\mathrm{L}$. showed dose-dependent decrease in body temperature when compared against control as well as against paracetamol (standard) group (Tables 1-3 and Fig. 2).

\section{Antiulcer studies}

All three test doses of the ethanolic extract of leaves of T. orientalis $\mathrm{L}$. showed dose-dependent decrease in UI when it was compared against control as well as against pantoprazole, which was used as a standard (Tables 4-6 and Figs. 3-5)

LPO

LPO is mentioned in Table 6.

\section{DISCUSSION}

T. orientalis showed the inhibition of the increase in rectal temperature in albino Wistar rats in dose-dependent manner; it can be due to inhibition of inflammatory mediators such as cyclooxygenases, interleukins, or prostaglandins.

Ethanol produces massive intracellular accumulation of calcium, which represents a major step in the pathogenesis of gastric mucosal injury. This leads to cell death and exfoliation in the surface epithelium.

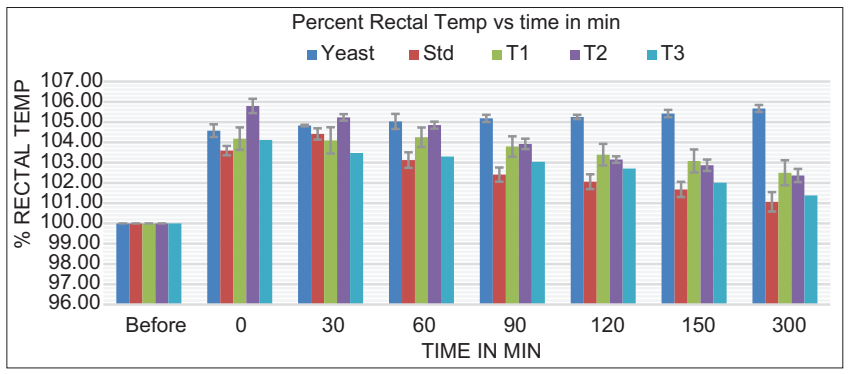

Fig. 2: Effect of ethanolic extract of Trema orientalis $L$. leaves on percent change in rectal temperature yeast-induced pyrexia in albino Wistar rat

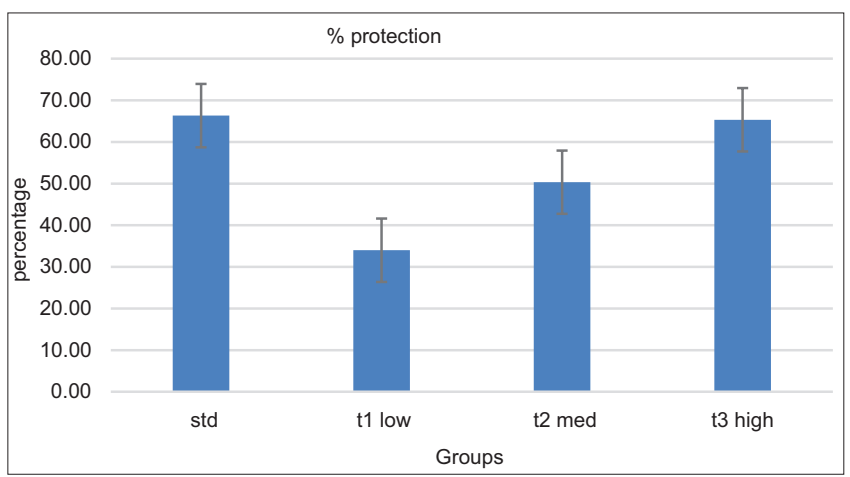

Fig. 3: Effect of ethanolic extract of Trema orientalis $L$. leaves on percent ulcer in albino Wistar rats calculated by Ganguly and Bhatnagar formula

Ethanol also acts on mitogen-activated protein kinase-II to release inflammatory mediators, which ultimately causes the mucosal injury. The antiulcer property of $T$. orientalis in ethanol-induced ulcer model is evident from its significant reduction in total acidity, gastric volume, LPO, number of ulcers, and UI.

The preliminary phytochemical analysis of T. orientalis extract showed the presence of alkaloids, flavonoids, triterpenoids, carbohydrates, and glycosides. The significant increase in the antiulcer activity of 


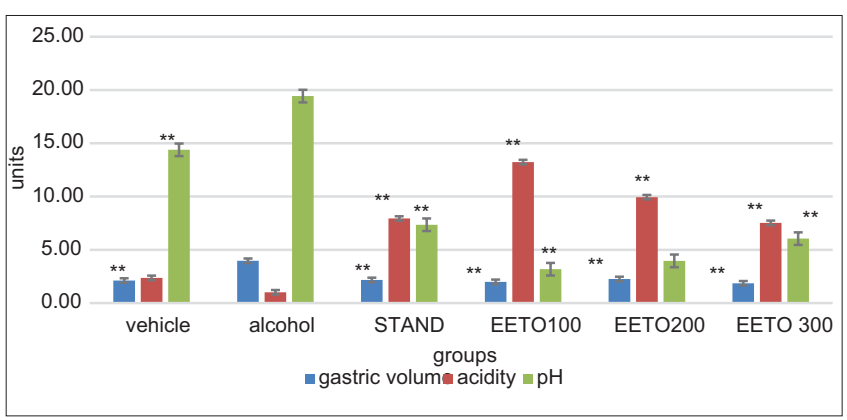

Fig. 4: Effect of ethanolic extract of Trema orientalis L. leaves on gastric volume, total acidity, and $\mathbf{p H}$ parameter in albino Wistar rats. Significance ${ }^{* *} p \leq 0.01$, $*$ indicates $p \leq 0.05$ when compared with negative control

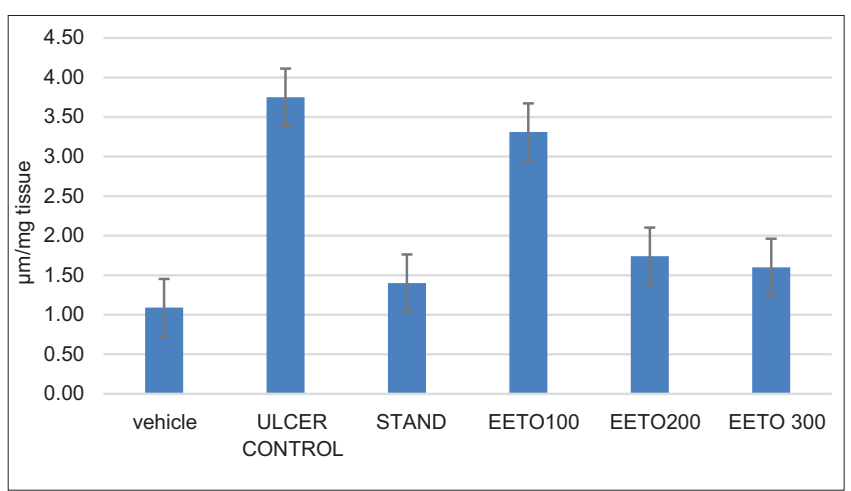

Fig. 5: Effect of ethanolic extract of Trema orientalis $L$. leaves on lipid peroxidation parameter in albino Wistar rats

T. orientalis could be attributed to the presence of flavonoids, alkaloids, tannins, saponins, glycosides, and phenolic compounds. Flavonoids are among the cytoprotective materials for which antiulcerogenic efficacy has been extensively confirmed. It is suggested that these active compounds would be able to stimulate mucus, bicarbonate, and prostaglandin secretion and counteract with the deteriorating effects of reactive oxidants in gastrointestinal lumen. Hence, the antiulcer activity of T. orientalis may be attributed to its flavonoids content.

The results of the present study suggest that the ethanol extract of $T$. orientalis leaves may be beneficial in the treatment of gastric ulcer induced by aggressive factors. Further studies to identify the active moieties and elucidation of the mechanism of action are recommended.

\section{CONCLUSION}

The present study does confirm that the ethanolic extract of T. orientalis does exhibit significant dose-dependent antipyretic and antiulcer activity. The bioactivity-guided phytochemical screening of EETO revealed the presence of flavonoids, tannins, and triterpenoids, which may be responsible for the antiulcer effect and can be further fractionated and investigated for their role and utility in any of the antiulcer mechanisms.

\section{ACKNOWLEDGMENT}

We are grateful to our Principal, Dr. (Mrs.) Sudha Rathod and Dr. (Mrs.) Vanita. G. Kanase, for their guidance and support as well as to Pharmacology Department, Oriental College of Pharmacy, Navi Mumbai.

\section{AUTHORS' CONTRIBUTION}

Jyoti Singh collected the clinical samples and carried out antipyretic, antiulcer, and biochemical investigations and drafted the manuscript. Dr. (Mrs.) Vanita Kanase proof-read the whole manuscript and suggested the necessary changes and helped in designing manuscript.

\section{CONFLICTS OF INTEREST}

The authors declare that there are no conflicts of interest regarding the publication of this paper.

\section{REFERENCES}

1. Harbison S, Dempsey D. Peptic ulcer disease. Curr Probl Surg 2005;42:346-454.

2. Sharma D, Bhatt S. A comprehensive review on ulcer healing potential of medicinal plants. Int J Pharm Pharm Sci 2014;6:201.

3. Dimo T, Ngueguim FT, Kamtchouing P, Dongo E, Tan PV. Glucose lowering efficacy of the aqueous stem bark extract of Trema orientalis (Linn) blume in normal and streptozotocin diabetic rats. Pharmazie 2006;61:233-6.

4. Jiji KN, Pramod C, Prasad BS, Muralidharan P, BaidMetha CL. Evaluation of antidiabetic activity of ethanolic extract of Trema orientalis (L.) blume leaves. IOSR J Pharm Biol Sci 2016;11:17-26.

5. Abiodun O, Gbotosho G, Ajaiyeoba E, Happi T, Falade M, Wittlin S, et al. In vitro antiplasmodial activity and toxicity assessment of some plants from Nigerian ethnomedicine. Pharm Biol 2011;49:9-14

6. Orwa C, Mutua A, Kindt R, Jamnadass R, Simons A. Agroforestree Database: A Tree Reference and Selection Guide Version 4.0, 2009. Available from: http://www.worldagroforestry.org/af/treebd. [Last accessed on $2009 \mathrm{Feb} 18]$.

7. Olanlokun JO, David OM, Afolayan AJ. In vitro antiplasmodial activity and prophylactic potentials of extract and fractions of Trema orientalis (Linn.) stem bark. BMC Complement Altern Med 2017;17:407.

8. Uddin SN, Uddin KM, Ahmed F. Analgesic and antidiarrhoeal activities of Trema orientalis Linn in mice. Orient Pharm Exp Med 2008;8:187-91.

9. Panchal HS, Master SM, Shah UD, Saluja AK, Dholwani KK. Anticonvulsion activity of leaf of Trema orientalis. Int J Pharm Res 2010;2:53-5

10. Barbera R, Trovato A, Rapisarda A, Ragusa S. Analgesic and antiinflammatory activity in acute and chronic conditions of Trema guineense (schum. etThonn.) Ficalho and Trema micrantha Blume extracts in rodents. Phytother Res 1992;6:146-8.

11. Chowdhury A, Islam MS. Antibacterial activity of Trema orientalis. Dhaka Univ J Pharm Sci 2004;3:115-7.

12. McGaw LJ, Jäger AK, van Staden J. Antibacterial, anthelmintic and antiamoebic activity in South African medicinal plants. J Ethnopharmacol 2000;72:247-63

13. Diehl MS, Atindehou KK, Téré H, Betschart B. Prospect for anthelminthic plants in the ivory coast using ethnobotanical criteria. J Ethnopharmacol 2004;95:277-84.

14. Mpiana PT, Ngbolua KN, Mudogo V, Tshibangu DS, Atibu EK, Tshilanda DD, et al. Anti sickle erythrocytes haemolysis properties and inhibitory effect of anthocyanins extracts of Trema orientalis on the aggregation of human deoxyhemoglobin $\mathrm{S}$ in vitro. J Med Sci 2011;11:129-37.

15. Salprima YS, Eka A, Sri N, Syalfinaf M, Anggria MS, Fatan U. Iron chelating and antiradical activity of kayumanik leaves (Trema orientalis). Indo J Chem 2011;11:196-9.

16. Hossain E, Mandal SC, Gupta JK. Phytochemical screening and in-vivo antipyretic activity of the methanol leaf-extract of Bombax malabaricum DC (Bombacaceae). Trop J Pharm Res 2011;10:55-60.

17. Busia K. Ghana Herbal Pharmacopeia Accra. Ghana: The Adventist Press; 1992. p. 141-3.

18. Borrelli F, Izzo AA. The plant kingdom as a source of anti-ulcer remedies. Phytother Res 2000;14:581-91.

19. Di Carlo G, Mascolo N, Izzo AA, Capasso F. Flavonoids: Old and new aspects of a class of natural therapeutic drugs. Life Sci 1999; 65:337-53.

20. Galati EM, Monforte MT, Tripodo MM, d'Aquino A, Mondello MR. Antiulcer activity of Opuntia ficus indica (L.) mill. (Cactaceae): Ultrastructural study. J Ethnopharmacol 2001;76:1-9.

21. Khandelwal K. Practical Pharmacognosy. Maharashtra: Nirali Prakashan; 2008.

22. Akapa TC, Kehinde AO, Beatrice OO, Joseph O. Antipyretic activity of Abutilon mauritianum (Jacq.) roots in Wistar rats. Int J Pharma Sci Res 2014;5:42-6.

23. Priya S, Nethaji S. Antipyretic Activity of ethanolic extract of leaf and bark of Diospyros virginiana in yeast induced pyrexia. Int J Pharm Pharm Sci 2015;7:502-4

24. Loux JJ, Deplama PD, Yankel SL. Antipyretic testing of aspirin in rats. Toxicol Appl Pharmacol 1972;22:672-5.

25. Sathish R, Kumar PS, Natarajan K, Sridhar N. Hepatoprotective and 
anti pyretic activities of methanolic extract of Butea monosperma Lam stem bark in Wister rats. Asian J Pharm Res 2011;1:130-3.

26. Surwase US, Shaikh GH, Patil SM, Hunsnalkar SG, Chaudhary RY. Phytochemical investigation and preliminary pharmacological screening of Alstonia scholaris R. Br. As an antipyretic. Asian J Res Chem 2009;2:304-5.

27. Valli G, Vijayalakshmi R, Vasanthi A, Thirupathi AT. Studies of antipyretic and anti-inflammatory activities of odina woodier leaves extracts. Res J Pharmacol Pharmacodyn 2011;3:263-7.

28. Patil SB, Chavan GM, Ghodke DS, Naikwade NS, Magdum CS. Screening of some indigenous plants for their antipyretic activity. Res J Pharmacol Pharmacodyn 2009;1:143-4.

29. Kumar B, Singh A, Kaur M. Comparative antidiarrheal and antiulcer effect of the aqueous and ethanolic stem bark extracts of Tinospora cordifolia in rats. J Adv Pharm Tech Res 2014;5:122.

30. Parsons ME. Pantoprazole, a new proton-pump inhibitor, has a precise and predictable profile of activity. Eur J Gastroenterol Hepatol 1996;8 Suppl 1:S15-20.

31. Shin JM, Sachs G. Pharmacology of proton pump inhibitors. Curr Gastroenterol Rep 2008;10:528-34

32. Oates PJ, Hakkinen JP. Studies on the mechanism of ethanol-induced gastric damage in rats. Gastroenterology 1988;94:10-21.

33. Rathnakumar K, Jaikumar S, Sengottuvelu S. Antiulcer activity of Euphorbia hirta against experimentally induced ulcer in rats. Asian J Pharm Res 2013;3:122-4.

34. Mahurkar N, Hasan SMS. Antiulcer activity of Commicarpus Chinensis in ethanol and aspirin induced ulcers. Asian J Pharm Res 2014;4:119-22.

35. Girish C, Vineela S, Reddy YN, Reddy OV, Rajasekhar KK,
Shankarananth V. Evaluation of antiulcer activity of Coccinia grandis leaves. Res J Pharmacol Pharmacodyn 2011;3:92-5.

36. Kumar V, Bhat Z, Kumar D, Khan N, Chashoo I, Ara I. Gastroprotective effect of leaf extracts of Basella alba var. Alba against experimental gastric ulcers in rats. Rev Bras Farmacognosia 2012;22:657-62.

37. Divakar M, Devi S. Antiulcer activity of Wrightia tinctoria (Roxb.) R. Br. Pharm Sin 2018;2:355-60.

38. Dhanaraj TS, Murugaiah K, Sarmila. Antiulcer activity of Mukia maderaspatana on stress induced in rats. Asian J Res Pharm Sci 2012;2:52-4.

39. Mahurkar SM, Hasan SU, Malpani AA. Gastroprotective influence of Vitamin $\mathrm{C}$ and its combination with rabeprazole in pylorus ligation induced ulcers. Asian J Res Pharm Sci 2014;4:71-6.

40. Ganguly AK, Bhatnagar OP. Effect of bilateral adrenalectomy on production of restraint ulcers in the stomach of albino rats. Can J Physiol Pharmacol 1973;51:748-50.

41. Malairajan P, Gopalakrishnan G, Narasimhan S, Veni KJ, Kavimani S. Anti-ulcer activity of crude alcoholic extract of Toona ciliata Roemer (heart wood). J Ethnopharmacol 2007;110:348-51.

42. Rathod S, Motghare V, Deshmukh V. Study of antiulcer activity of angiotensin receptor antagonists in experimentally induced gastric ulcers in rats. Int J Pharm Sci Res 2014;5:502-7.

43. Swathi D, Prasad KV. Antioxidant and antiulcer potential of ethanolic extract of bark of Myrica esculenta in pyloric ligation ulcer model. Int J Pharm Pharm Sci 2015;7:195-8.

44. Ghaisas MM, Sharma S, Ganu GP, Limaye RP. Antiulcer activity of Colebrookea oppositifolia SM. Res J Pharmacol Pharmacodyn 2010;2:66-70 